\title{
Paideusis
}

\section{The Complexities of Reasons: A Critical Review of Siegel's Rationality Redeemed?}

\author{
Frederick S. Ellett, Jr. and David P. Ericson
}

Volume 11, Number 2, 1998

URI: https://id.erudit.org/iderudit/1073101ar

DOI: https://doi.org/10.7202/1073101ar

See table of contents

Publisher(s)

Canadian Philosophy of Education Society

ISSN

0838-4517 (print)

1916-0348 (digital)

Explore this journal

Cite this article

Ellett, Jr., F. \& Ericson, D. (1998). The Complexities of Reasons: A Critical Review of Siegel's Rationality Redeemed? Paideusis, 11(2), 3-12.

https://doi.org/10.7202/1073101ar

(C) Frederick S. Ellett, Jr., David P. Ericson, 1998

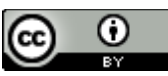

This document is protected by copyright law. Use of the services of Erudit (including reproduction) is subject to its terms and conditions, which can be viewed online.

https://apropos.erudit.org/en/users/policy-on-use/
This article is disseminated and preserved by Érudit.

Érudit is a non-profit inter-university consortium of the Université de Montréal, Université Laval, and the Université du Québec à Montréal. Its mission is to promote and disseminate research.

https://www.erudit.org/en/ 


\title{
The Complexities of Reasons: A Critical Review of Siegel's Rationality Redeemed?
}

\author{
Frederick S. Ellett, Jr., University of Western Ontario and \\ David P. Ericson, University of Hawail at Manoa
}

\section{General Educational Position}

Rationality Redeemed? $(R R)$ is a collection of articles previously published by Harvey Siegel to which he has added an introduction. The book continues the ideas set out in his Educating Reason (1988). Siegel has roughly organized $R R$ into two parts. The first tries to develop and defend the following: that "rationality, and what I call . . . its educational cognate, critical thinking, constitute a fundamental educational ideal" $(R R$, pp. 1,4$)$; that the "fostering of rationality and critical thinking is the central aim and the overriding ideal of education ( $R R, \mathrm{p} .2)$; and that an "education aimed at fostering critical thinking is morally obligatory" (RR, p. 63). The second part of the book considers various critiques of this position put forward by contemporary contextualists, feminists, multiculturalists, and postmodernists. Such critics "manifest radically different approaches to philosophy and philosophy of education" $(R R, \mathrm{pp}$. 4,8 ), and so, "either radically reconceive [Siegel's] ideal or reject it outright."

Siegel is sincere in his "attempt to embrace what is right in such critiques [and] to demonstrate some of the ways these critiques do not succeed"' $(R R, \mathrm{p}$. 8). During a period when many have, at best, tacitly resisted the newer "philosophical voices," Siegel has stood out for his willingness to engage in conversations in search of shared and reasonable views.

Throughout his work, Siegel employs quite a broad conception of "critical thinker." A critical thinker must not only have the skills and abilities which facilitate or make possible the appropriate assessment of reasons, but must have certain dispositions, habits of mind, and character traits as well $(R R, p .2)$. As Siegel likes to say, a critical thinker is one who is "appropriately moved by [good] reasons." For Siegel, the relationship between critical thinking and rational thinking is very close for he takes rationality to be having good reasons. In many ways, then, Siegel's critical thinker is closely related to a rational, free, and responsible agent (see Rawls, 1993). Siegel's critical thinker is also closely related if not identical with William Hare's (1985) open-minded person.

Siegel's critical thinker stands in sharp contrast to Paul Hirst's liberally educated person. The latter does not have encyclopaedic knowledge, does not have a specialist knowledge of one trained in details, and does not have a technician's knowledge of detailed application. Hirst's ideal has merely sufficient immersion in the concepts, logic, and criteria of the disciplines so that the person comes to know the distinctive way in which it 'works' and comes to have one's experience widely structured in the distinctive manners of the domains. As Hirst $(1975$, p. 18) put it, "[I]t is the ability to recognize empirical assertions or aesthetic judgements for what they are, and to know [merely] the kind of considerations on which their validity will depend, that matters." For Hirst, this kind of understanding is most readily distinguishable as "critical appreciation" $(1975$, p. 19). In contrast, Siegel's critical thinker (and Hare's open-minded person), given their illustrative examples, might aptly be called a renaissance (or super-liberally educated) person. 
Siegel and Hare rightly see that rationality continues to come under serious attack from many sides. Siegel holds that it is a legitimate philosophical task to defend the claim about rationality's being the fundamental educational aim. Hare holds that it is also a legitimate philosophical task to worry about whether the ideal is "utopian, about whether and how it can be realized." In this respect, Hare's work nicely complements Siegel's. Here, we argue briefly that both views need a minor modification to take into account the role of "trust" and "authority." Hooker (1987) has argued that less than ten percent of today's physicists understand the basic equations of modern physics. Hooker (1987) and Putnam (1990) argue, therefore, that there is a division of labour within most forms of collective inquiry. Within each discipline, there is legitimate trust and respect for the legitimate intellectual authority of others (see also Elgin, 1996; Lycan, 1988). It turns out, then, that much of what we come to believe and come to know does not result from having direct evidence but from trusting legitimate authorities. The appropriate education, then, will differ from a "super-liberal education" for it will involve a balance between trust in the reliable authorities and independent reason. With this modification, the Siegel/Hare views become defensible and feasible! Neiman and Siegel (1993, p. 60) often stress the institutional (collective) aspects of rationality; Siegel (1997) rarely does (see Black, 1983a).

\section{Siegel's Fallibilism and Science}

Siegel's work involves a sustained attempt to explicate and defend rationality as a fundamental, educational ideal. To do this, Siegel spends most of the time explicating and defending what he calls "fallibilism": even if a claim is justified, there is a chance it is false.

Siegel and Hare have both claimed that rationality is just having good reasons. In contrast, we agree with Max Black's analyses $(1975,1983 \mathrm{~b})$ that the claim is really a semi-stipulative definition which needs a second-order legitimation. (We will return to explicate this term.) Black (1983a) and Rescher (1988) appear to hold that rationality is the pursuit of appropriate ends by intelligent means. Still, we believe the basic Siegel/Hare claim, when suitably modified, can be so justified. We also believe that Siegel has a rather expanded sense of "critical thinker." But, whatever one calls them, they are very important.

We believe that the most important aspect of Siegel's book is his firm, intuitive sense of the fundamental philosophical issue at stake. Very few educators have grasped the issue; almost all of his critics fail to grasp it. (Kohlberg and Gilligan have failed, too!) As we will see, Siegel does not seem to help us by calling his view the "old-time enlightenment metanarrative" and by saying that the partial (objective) success of his various critics actually depend upon the very Enlightenment conceptions and ideals that the critics challenge $(R R$, p. 8). Siegel does not really restrict himself to the Enlightenment ideals; he says that this ideal is the most widely advocated in the history of philosophy of education from Plato to Dewey and beyond (p. 189, fn. 1; p. 216, fn. 28).

Let us start by comparing Siegel's views with Hirst's. Hirst's justification of liberal education rests in large part on the claim that "[j]ustification is possible only if what is being justified is both intelligible under publicly rooted concepts and assessable according to accepted criteria" (1975, p. 13). Hirst 
holds, then, that judging according to public standards is a necessary condition of objective justification. But Siegel holds that, even if it is necessary, it is clearly not enough: justifying a candidate by showing it "fits with current practice" (or "accords with practice") cannot be sufficient for it to be justified (1992, pp. 42-3). Mackie (1977) is well-known for putting it this way:

The subjectivist [that is, the skeptic] about values [reasons] . . . is not denying that there can be objective evaluations relative to standards, and these are possible in aesthetic and moral fields as in [any field that calls for expertise and invokes standards]. But the statement that a certain decision is just or unjust will not be objectively prescriptive: insofar as it can simply be true, it leaves open the question whether there are any objective requirements to do what is just and to refrain from what is unjust, and equally leaves open the practical question to act in other ways. (pp. 26-27)

Here Mackie is challenging the claim that there is any objectivity in moral discourse. Mackie, of course, never considered denying objectivity in the sciences. Richard Rorty has denied that science is objective! Of course, Rorty is not about to reject the teachings of modern science; he does accept the (firstorder) reasons and criteria of the current practice. But when asked for a justification of science, he says that none is to be had. He claims that all one can say is "This is what we do." Objectivity is, somehow, connected with legitimation (justification). So, Rorty argues we should give up on "objectivity" and settle for "solidarity," or "ethnocentrism" (1991a). Self-described followers of Rorty sometimes say "reflexive ethnography" is all we need (Stout, 1988, pp. 72,228 ; but also see pp. 73,282 ). Similarly, David Hume was not about to renounce the beliefs, concepts, and values he held in his den; Hume's skepticism pertains to these being justified or objective in the philosophical sense.

Siegel $(R R$, pp. 174-5) is rightly opposed to Rorty as we will show. Siegel $(R R$, p. 204, fn. 10) is also rightly opposed to Quine's (1969) "epistemology naturalized," an approach that tries to reduce considerations of objective justification to the first-order findings of psychology. It appears that Siegel takes Quine (1969) to define what the "naturalistic approach" to philosophy is. It may be that Siegel thinks that an account of legitimation involves a choice between a Quinean naturalist and a Kantian transcendentalist. Siegel's frequent remarks about transcendental methods and $a$ priori methods suggest that Siegel really is some kind of Kantian (see "Epilogue"; pp. 200, 216, 219). This would also explain why Siegel often seeks help from the strong neo-Kantians (Apel, Habermas, and Thomas Nagel). If Siegel thinks these two are the only viable accounts, then this is a serious mistake. Hahlweg and Hooker (1989), Hooker (1987), Margolis $(1989,1995)$, and Putnam $(1987,1990)$ have all called themselves "naturalists_even, pragmatists"!_-and all of them reject Quine (1969). Even Quine (1992) now sees difficulties with the earlier Quine (1969). Furthermore, all of them reject Rorty's arguments! If Siegel is really a strong Kantian who seeks necessary truths (and who would really reject naturalism), then this review is no longer a sympathetic and constructive criticism. We follow the naturalists who argue that the strong Kantian program fails. We believe that the naturalism of Hooker, Margolis, and Putnam (following the lead of Nelson Goodman and Morton White in the late 1940s) provides a comparatively plausible view.

The best way to grasp the fundamental issue is the following. It is reason- 
able to hold that philosophy addresses three questions: (1) what do we take to be the nature of the real world, and why? (2) what do we take to be the extent of our ability to have knowledge of the real world, and why? and (3) having answered those questions, how should we live our lives, and why? Consider the first question. Let us say that, broadly speaking, questions of fact, questions about the way the world is or appears to us to be, in terms of ordinary inspection, activity, scientific inquiry, and the like, are first-order questions (questions for first-order discourse). In contrast, questions about what, in the most critical sense, we take it we should mean, as in speaking of reality and knowledge, will be second-order questions (questions for second-order discourse). First-order questions are questions about the way the world is, while second-order questions are questions about the right use of the concepts of reality and knowledge decided in the most responsible way we can manage. Thus, the concern of second-order philosophical questions is legitimation-the reasoned or critical justification of an account of what reality or knowledge is, or should be taken to be, under the condition of admitting a suitable run of first-order instances of actual (apparent) knowledge (see Hooker, 1987, Ch. 3, 8; Margolis, 1989; Margolis, 1995, Ch. 1, 2, and 11). Siegel (1992, p. 44) appears to accept this characterization. First-order inquiries without second-order inquiries cannot but be incomplete and blind; second-order inquiries without first-order inquiries cannot but be empty.

Given this distinction between first-order and second-order discourse, one can see that Kant's transcendental method is but one way to carry on secondorder discourse. Foundationalism is another way. The naturalistic approach of Hooker, Margolis, and Putnam (and, we think, Elgin (1983, 1996), Goodman, Scheffler (1986), and Quine (1992)) is yet another way to carry on second-order discourse. Here, it is important to see that the Western philosophical project has traditionally relied on a viable distinction between first-order and second-order discourse. As Rorty says, and Hooker, Margolis, Putnam, and Siegel agree, if the distinction were not viable, then philosophy really would be dead.

Naturalists say that there is no FIRST philosophy. A FIRST philosophy holds that philosophy must start from necessary principles or constraints. For example, Aristotle held that it must be the case that nature has a fixed structure and human beings have a fixed nature (or essence); Aristotle held that to deny it is to contradict oneself. But Aristotle's argument is invalid (Maclntyre, 1984, tacitly agrees). In a formal system, it is a necessary falsehood that a thing can be $F$ and not-F. But in an actual inquiry, it is not necessarily false, for one can always choose to reinterpret the terms. Thus, real numbers can be "irrational," parallel lines can meet, a thing can be both a particle and a wave, and so on. (Such changes helped motivate Quine's critique of the analytic-synthetic distinction.)

Siegel ( $R R$, p. 23) holds an "absolute conception of truth": (1) the true cannot be defined relative to any epistemic properties and (2) for any proposition P, P is either true or false (see Scheffler (1965), p. 47). But the second aspect is not unconditionally necessary; it is not an $a$ priori truth that for any proposition $\mathrm{P}, \mathrm{P}$ is either true or false. Multi-valued logics are not logically incoherent. Several philosophers (Elgin (1983, 1996), Margolis (1989, 1995, 1996), Putnam (1990), Quine (1992)) have argued that, depending upon the nature of the domain of systematic inquiry, a multi-valued logic may well be 
defensible. A multi-valued logic would distinguish the false from the more plausible, but would it leave open whether there is an uniquely plausible theory in the domain. One could find two theories which are incongruent but equally plausible; one need not reject one of them. If science can distinguish the false from the more plausible but leave it open whether there is an uniquely plausible theory, then we should not expect more in other domains-for example, morality. (The use of a multi-valued logic in literary criticism would totally obviate the "nihilist interpretation given by Neiman and Siegel (1992, p. 74).)

Rorty (1991a) himself advocates giving up "bivalence." Here, it is clear that Rorty is being arbitrary, for he will just say he switched! But our considering whether it would be appropriate to change from using a bivalent logic to multi-valued logic is a second-order discourse for which our best second-order reasons can be given for and against each option. Again, Siegel (1992, p. 44) appears to accept this general point (see, also, Elgin (1983, 1996); Margolis (1989,1995); Quine (1992); Scheffler (1986a, b)).

Recall that Siegel is a fallibilist. Indeed, “. . . we are all fallibilists now, and have been since Peirce" (RR, p. 164). If so, we surely are not all fullbodied Peirceans! For Quine (1960) has shown that Peirce's attempt to define "true" (and the "real") in terms of the long-run outcome of the community of inquirers does not work; Quine showed that it is neither an a priori nor an empirical truth that the long-run inquiry must converge to a unique theory. (The early Habermas (1968) had built upon the unsound Peircean view.)

Peirce was, of course, one of the first to grasp the significance of probability in modern science (see Scheffler, 1986c). Throughout his work, Siegel makes use of and stresses the important epistemic role for probability. But the concept of probability is not universal in the sense that all rational inquirers have it. It was invented about three hundred years ago and has undergone significant changes before it achieved the epistemic role it has today. Even today, the concept has important problems.

Siegel suggests that a concept or criterion is universal because it is binding on all rational inquirers. But how can Siegel know that the concept of probability is universal? How can he show that the concept we use today will be the same one that all our rational descendants will be using? Even if a similar concept were in use, perhaps the differences would be so great that one would say it was really a different concept! As Popper has warned us, one cannot predict the direction of knowledge growth!

The naturalists claim that "there is no first philosophy" is an inductive conjecture-a rational bet. For example, given that there is no a priori need for certain foundations, and given that all attempts to discern certain foundations have failed so far, we rationally bet that none will be found in the future. But this is a risky bet, not a sure thing. Hence, the claim that there is no FIRST philosophy does not itself have the status of a necessary truth. The claim is not self-reflexively self-defeating. Siegel's version of fallibilism should be understood in this way. When it is so understood, there is no need for Siegel's ad hoc and arbitrary defence $(R R$, p. 122$)$.

In the naturalistic spirit, then, we are entitled to reject reliance on the modalities, whether logical, natural, or linguistic, as fundamentally unclear. Necessity in all its guises is, thus, abjured and the notion of analyticity as well. Accordingly, the quest for certainty based upon meaning is wholly abandoned. 
(These three sentences are from Scheffler (1986), p. xi). We have substituted "naturalistic" for Scheffler's word "nominalistic." We believe Scheffler can be interpreted as our kind of naturalist (pragmatist). Neiman and Siegel appear to accept this conclusion about fixity. Indeed, they praise Scheffler for recognizing that objectivity does not require fixity of any sort and that there "need not be any necessary understandings of permanent criteria" (1993, pp. 62-3). The naturalist would add that, if one may start without having necessary truths, knowledge also has to be reconceived so that it yields provisional solutions rather than necessary truths (see Scheffler (1986)). Siegel concedes that it is impossible to achieve a "God's-eye point of view" (RR, pp. 150, 175; p. 215, fn. 25). A naturalist would add that it is also impossible to achieve a God-like necessary framework for all inquiry.

Here, the naturalist joins forces with such postmodernists as Rorty and Lyotard. For example, what Lyotard calls a "metanarrative" includes such things as "the necessary march of the proletariat" (Marx) and "the necessary unfolding and cunning of reason" (Hegel). The naturalist and the postmodern argue that these views (which involve such unconditional necessities) are epistemically inaccessible!

Rorty has repeatedly argued (1991a, b) that philosophy has shown that Kant's project to find universal-and-necessary truths or constraints has been a failure. For Rorty, philosophy has lead us to see the contingency of various concepts, rules, and principles. But Rorty, Lyotard, and Mackie go on to argue that only a Kantian account of objectivity and legitimation will do! Given that the Kantian account fails, the postmodern claims that the philosophical project of legitimation fails. We argue that postmodernism is mistaken, for it has arbitrarily overlooked the naturalistic approach to legitimation.

The view that there is no FIRST philosophy (or the position of fallibilism) cannot just be a negative criticism to other approaches. If one rejects Peirce's second-order account, as one should, then one needs to develop a new account. To talk about fallibilism without offering a positive account is to be left with a vacuous view. (See, for example, Bernstein (1991) for one such nearly vacuous account.) One must develop a positive theory of inquiry which co-ordinates epistemology, a theory of truth, and ontology. But Siegel (1997) does not go nearly far enough. He holds that ". . c claims which are rationally justified are claims which we have reason to regard as true" (p. 22); Siegel says this is a conceptual truth. But the work of van Fraassen (1980) shows this is not a conceptual truth. Scientists can have good reasons for accepting a theory because it explains the phenomena and, yet, not take the theory to be true.

The major problem, however, is that Siegel never successfully links rationality or epistemology to any ontological position. Neiman and Siegel do argue that maximizing the epistemic credibility or coherence of the entire system is not enough; they hold that objective utterances need also to have referential import (1993, p. 65). Neiman and Siegel appear to follow the work of Scheffler $(1965 / 1982)$ who had tried to show that in a mature field of inquiry, the terms typically refer to what they purport to refer and the laws of nature are approximately true. When Scheffler is read this way, he clearly had anticipated the well-known Putnam-Boyd view (see Putnam, 1978). But Putnam (1987, 1990) rightly came to regard such claims as a question-begging defence of realism. If a realism is to be defended, it will have to be in a more indirect, 
holistic manner. The first step starts ffom fact that the technologies related to modern physical science are causally powerful and effective. One then reasonably infers from this that modern science is somehow in touch with reality (see Hooker, 1987; Lycan, 1988; Margolis, 1989, 1995). Linking rationality and a "minimal realism" will also help provide a viable answer to certain kinds of skeptic who ask "Why should I be rational?" by showing how one's ends can be achieved ( Black,1983b; Rescher, 1988).

\section{Siegel's Moral Stance and Fallibilism}

Siegel holds that he can provide four reasons to justify critical thinking as the fundamental educational ideal: respect for students as (potential?) persons; self-sufficiency and preparation for adulthood; initiation into the rational traditions; and democratic living ( $R R$, p. 4). Given that he holds the fundamental justification is the first one, the moral one $(R R$, p. 4$)$, it is surprising how little Siegel has to say about it. We will provide two reasons for thinking that his Kantian line of argumentation has grave difficulties.

Throughout his writings, Siegel has claimed that the key notion is the Kantian notion of equal respect for persons ( $R R$, pp. 93-4). There is, of course, a well-known literature that is quite critical of any Kantian approach to ethics. Albert (1985), Arrington (1989), Larmore (1987, 1996), MacIntrye (1984), Mackie (1977), Margolis (1996), Stout (1988), and Williams (1985) have argued that there are very serious problems with the Kantian approach. Let us suppose that Kant's general strategy (reasoning to discover transcendentally necessary constraints binding upon itself) fails to explain the strict necessary of what it claims to find. Or, let us suppose that Kant's approach fails to explain why the seeming necessity should not be construed as an artifact of its own inquiry. Given that either of these suppositions holds, it very hard to see how Karl-Otto Apel (1980) or Habermas (1990) can carry out their programs. Hans Albert (1985) has argued, correctly we think, that if one seeks an absolute foundation for knowledge (in the form of necessary constraints on inquiry), then any concession to fallibilism will result in failure. Part of the significance of Albert's work is that his critique has drawn responses from both Apel and Habermas, responses which just do not answer the criticism. Recall that Siegel is a fallibilist. At any rate, if Kant's (or Apel's) a priori methods cannot secure the desired necessary truths, then Habermas's use of $a$ posteriori means can do no better (see Margolis, 1989; Margolis, 1995, Ch. 8, 11; Margolis, 1996).

Those who are still sympathetic to Kant, such as Hill (1991) and Rawls (1993), have modified their views in major ways. For example, Rawls (1993) concedes that practical rationality is not enough to justify (his) liberal principles. Rawls (1993) tries to show that one must add the normative notion of reasonableness.

In the current discussions about the justifiability of certain political/social principles in a pluralistic society, it is conceded, at the start, that any appeal to the Kantian ideal is quite unhelpful. In a pluralistic society, many persons will reasonably not be Kantians. Therefore, to justify the principles governing the basic structures of society, one must develop some other line of argumentation (see Larmore (1987, 1996); Rawls (1993). Similar difficulties hold for utilitarianism such as that adopted by Hare (1985, Ch. 3). Habermas, Kant, and Rawls share the belief that all the legitimate views of the good life can live 11(2), (Winter) 1998 
together in one society. But Berlin (1991/1997) has argued that some of "the Great Goods cannot live together." Rawls (1993) has accepted Berlin's claim, but Rawls has failed to see that it means that not all of the legitimate interests in a society can be satisfied in that society. He has failed to see how it undermines his search for a consensus position. Habermas's attempt (1990, pp. 65-66) to find principles which satisfy everyone's legitimate interests runs into the same problem. It appears, then, that even a broad Kantian approach does not appreciate the vast range of reasonable views of good lives. In any case, Rescher $(1988, \mathrm{Ch} .10)$ has argued that consensus is not a requirement for rationality.

The arguments of most moral skeptics such as Mackie, and Rorty imply that science itself is not objective. But we have pointed out that in the naturalist account science has both epistemic and ontic objectivity, even though there is no fixity of any kind. So, such a moral skeptic is defeated. We believe a positive account of moral objectivity is plausibly offered by the recent approach called "moral realism" or "cultural realism" (see, for example, the work of Arrington (1989) and Margolis (1995, 1996)).

\section{References}

Albert, Hans (1985). Treatise on Critical Reason, trans. Mary Varney Rorty. Princeton: Princeton University Press.

Apel, Karl-Otto (1980). "The a priori of the Communication Community and the Foundations of Ethics: The Problem of a Rational Foundation of Ethics in a Scientific Age." Towards a Transformation of Philosophy, trans. Glyn Adey and David Frisby. London: Routledge \& Kegan Paul.

Arrington, Robert L. (1989). Rationalism, Realism, and Relativism: Perspectives in Contemporary Moral Epistemology. Ithaca, NY: Cornell University Press.

Berlin, Isaiah (1991). The Crooked Timber of Humanity. New York: Knopf/ 1997 Princeton, NJ: Princeton University Press.

Bernstein, Richard (1991). "Pragmatism, Pluralism, and the Healing of Wounds." Appendix to The New Constellation: The Ethical Political Horizons of Modernity/Postmodernity. Cambridge, MA: MIT Press.

Black, Max (1975). "Rationality and Cultural Relativism." In M. Black ed.), Problems of Choice and Decision. Ithaca, NY: Cornell University Program on Science, Technology, and Society, 128-160.

Black, Max (1983a). "Reasonableness," The Prevalence of Humbug and Other Essays. Ithaca, NY: Cornell University Press.

Black, Max (1983b). "Why Should I be Rational?"' in Black (1983).

Elgin, Catherine Z. (1983). "Discourse On Method," Chapter X in With Reference to Reference. Indianapolis, IN: Hackett Publishing.

Elgin, Catherine Z. (1996). Considered Judgement. Princeton, NJ: Princeton University Press.

Habermas, Jurgen (1968). Knowledge and Human Interests, trans. Jeremy J. Shapiro. Boston: Beacon Press.

Habermas, Jurgen (1979). Communication and the Evolution of Society. trans. Thomas McCarthy. Boston: Beacon Press.

Habermas, Jurgen (1990). "Discourse Ethics: Notes on a Program of Philosophical Justification," Moral Consciousness and Communicative Action, 
trans. Christian Lenhardt and Shierry Weber Nicholsen. Cambridge, MA: MIT Press.

Hahlweg, Kai, \& Hooker, C.A. (Eds.) (1989). Issues in Evolutionary Epistemology. Albany, NY: SUNY Press.

Hare, William (1985). In Defence of Open-mindedness. Kingston/Montreal: McGill-Queen's University Press.

Hill, Thomas E., Jr (1991). Autonomy and Self-Respect. Cambridge: Cambridge University Press.

Hirst, Paul H. (1975). "Liberal Education and the Nature of Knowledge." In R.F. Dearden, P.H. Hirst, and R.S. Peters (Eds.), Education and Reason: Part 3 of Education and the Development of Reason. London: Routledge and Kegan Paul. Press.

Hooker, C.A. (1987). A Realistic Theory of Science. Albany, NY: SUNY

Larmore, Charles E. (1987). Patterns of Moral Complexity. Cambridge: Cambridge University Press.

Larmore, Charles E. (1996). The Morals of Modernity. Cambridge: Cambridge University Press.

Lyotard, Jean-Francois (1984). The Postmodern Condition: A Report on Knowledge, trans. Geoff Bennington and Brian Massumi. Minneapolis, MN: University of Minnesota Press.

Lycan William (1988). Judgement and Justification. Cambridge: Cambridge University Press.

MacIntrye, Alasdair (1984). After Virtue (2nd Edition). Notre Dame: University of Notre Dame Press.

Mackie, J.L. (1977). Ethics: Inventing Right and Wrong. Harmondsworth: Pelican.

Margolis, Joseph (1986). Pragmatism Without Foundations. Oxford: Basil Blackwell.

Margolis, Joseph (1995). Historied Thought, Constructed World: A Conceptual Primer for the Turn of the Millennium. Berkeley: University of California Press. Blackwell.

Margolis, Joseph (1996). Life Without Principles. Cambridge, MA:

Nagel, Thomas (1986). A View from Nowhere. New York: Oxford University Press.

Neiman, Alven and Siegel, Harvey (1993), "Objectivity and Rationality in Epistemology and Education: Scheffler's Middle Road," Synthese, 94(1), 55-83.

Putnam, Hilary (1978). Meaning and the Moral Sciences. London: Routledge and Kegan Paul. Court.

Putnam, Hilary (1987). The Many Faces of Realism. La Salle, IL: Open

Putnam, Hilary (1990). Realism With a Human Face, ed. James Conant. Cambridge, MA: Harvard University Press.

Quine, W.V. (1960). Word and Object. Cambridge, MA: MIT Press.

Quine, W.V. (1969). "Epistemology Naturalized," Ontological Relativity and Other Essays. New York: Columbia University Press. 
Quine, W.V. (1992). Pursuit of Truth (2nd Edition). Cambridge: Harvard University Press. sity Press.

Rawls, John (1993). Political Liberalism. New York: Columbia Univer-

Rescher, Nicholas (1988). Rationality. Oxford: Clarendon Press.

Rorty, Richard (1991a). "Introduction: Antirepresentation, Ethnocentrism, and Liberalism," Objectivity, Relativism, and Truth: Philosophical Papers, Volume 1. Cambridge: Cambridge University Press.

Rorty, Richard (1991b). "Habermas and Lyotard on Postmodernity," Essays on Heidegger and Others: Philosophical Papers, Volume 2. Cambridge: Cambridge University Press.

Scheffler, Israel (1965). The Conditions of Knowledge. Chicago: Scott, Foresman and Co.

Scheffler, Israel (1982/1967). Science and Subjectivity (2nd Edition). Indianapolis, IN: Hackett.

Scheffler, Israel (1986a). "Introduction," Inquiries: Philosophical Studies of Language, Science, and Learning. Indianapolis, IN: Hackett. Inquiries.

Scheffler, Israel (1986b). "On Justification and Commitment," in

Scheffler, Israel (1986c). "'Pragmatism as a Philosophy," in Inquiries.

Siegel, Harvey (1997). Rationality Redeemed? Further Dialogues on an Educational Ideal. New York and London: Routledge, 1997.

Siegel, Harvey (1992). "Justification by Balance," Philosophy and Phenomenological Research, 52(1), March, 27-46.

Siegel, Harvey (1988). Educating Reason: Rationality, Critical Thinking, and Education. London and New York: Routledge.

Stout, Jeffrey (1988). Ethics After Babel: The Languages of Morals and Their Discontents. Boston: Beacon Press.

van Fraassen, Bas C. (1980). The Scientific Image. Oxford: Clarendon Press.

Williams, Bernard (1985). Ethics and The Limits of Philosophy. Cambridge: Harvard University Press. 